\title{
Oral Versus Written Feedback: Attitudes of Female Saudi University Students
}

\author{
Jwahir Alzamil $^{1}$ \\ ${ }^{1}$ Assistant Professor, English Language Centre, Taif University, Kingdom of Saudi Arabia \\ Correspondence: Jwahir Alzamil, English Language Centre, Taif University, Taif, Kingdom of Saudi Arabia. \\ E-mail: dr.jawahir.tu@gmail.com
}

Received: August 21, 2021

Accepted: October 11, $2021 \quad$ Online Published: October 24, 2021

doi:10.5539/ijel.v11n6p84

URL: https://doi.org/10.5539/ijel.v11n6p84

\begin{abstract}
Oral and written feedback have been found to be useful in learning English as a Second Language (L2). Yet it is not clear what form of feedback L2 learners prefer. This study therefore investigated 47 Saudi female university students' attitudes to both oral and written feedback. The data was collected by an online questionnaire consisting of three constructs: a) attitudes to written feedback; b) attitudes to oral feedback; and c) attitudes to written versus oral feedback. In terms of the first, the results showed that most participants expressed positive attitudes to written feedback, which they would be happy to receive on all the mistakes they make in their writing. Most participants were also positive about oral feedback and wanted their teacher to correct all their speaking errors, including errors of grammar, pronunciation and vocabulary. However, participants did not want to be corrected in front of other students as this could make them nervous. Overall, most participants agreed that oral feedback helped them improve their English skills more than written feedback. But despite such a positive attitude, most participants still found oral feedback embarrassing. Knowing students' perceptions of corrective feedback (CF) is vital, because negative attitudes to feedback could harm the language learning process.
\end{abstract}

Keywords: English, L2 learning, oral feedback, university-level students, written feedback

\section{Introduction}

Making errors is a crucial part of learning English. However, when language teachers remain silent about their students' errors, students might assume this means that they performed well (Quinn, 2014). Teachers therefore need to use a variety of methods to help students see their mistakes and avoid them in future (Mahdi \& Saadany, 2013). One such method is CF. Teachers can use both oral and written feedback to correct students' errors, improve their learning and enhance their target language skills (Hadzic, 2016). However, provision of feedback does not automatically translate into students' acceptance. If students do not like the techniques used to correct errors, they may develop negative attitudes to them. Therefore, knowing students' attitudes towards CF can be very useful for language teachers, which is why they should take students' preferences for types of CF into consideration (Hyland, 2003).

The purpose of this paper is not only to raise teachers' awareness of the difference between oral and written feedback, but also to shed light on Saudi female university students' attitudes towards different types of feedback. Thus, this study aimed to address the following questions:

a. What are Saudi female university students' attitudes towards written feedback?

b. What are Saudi female university students' attitudes towards oral versus written feedback?

c. What are Saudi female university students' attitudes towards oral feedback?

\section{Literature Review}

\subsection{Corrective Feedback}

$\mathrm{CF}$ is a vital element of teaching which plays an important role in classrooms, and can help to improve learning (Lyster, Saito, \& Sato, 2013). Lightbown and Spada (1999, p. 71) broadly define CF as "any indication to the learners that their use of the target language is incorrect". It also has been defined as making a judgment about how well students have performed (Talib, Naim, \& Supie, 2015). CF can be both positive and negative. Positive feedback, implicit feedback, is a teacher's confirmation that validates a student's correct linguistic utterance in 
order to promote learning. On the other hand, negative feedback, explicit feedback, is a teacher's comment in response to a student's incorrect utterance (Lyster et al., 2013; Russell \& Spada, 2006). CF can be provided on both oral and written work. The next section discusses oral and written feedback.

\subsection{Oral and Written Feedback}

Oral CF can be divided into two categories: prompts and reformulations (Lyster \& Ranta, 1997). Prompts can take a variety of forms, including elicitation, metalinguistic clues, clarification requests and repetition. Recasts and explicit correction fall into the category of reformulation, as both offer students the correct answer (Ellis, Sheen, Murakami, \& Takashima, 2008). Because it is spoken, oral CF relies on learners' short-term memories, and requires an immediate cognitive comparison (Brookhart, 2008). However, it can be delivered as soon as an error occurs, or very soon afterwards, and may be between 5 and 10 minutes in length.

Conversely, written CF does not need to be given immediately, and may be delivered up to two days after task completion. Written feedback relies less on memory than oral feedback (Sheen, 2007), and can be either direct or indirect. Direct written feedback, which can provide learners with explicit error correction and help them amend and improve future work, can take a number of forms, including deleting and rewriting (Ellis, 2009). Indirect CF marks the location of errors in learners' writing without providing corrections, by highlighting, circling or underlining errors in their written texts (Ferris, 2002). Some of the research on students' attitudes to different types of feedback is discussed below.

Septiana, Daud and Heriansyah (2016) studied oral feedback. They looked at students' attitudes towards correction of the errors they make while speaking. Data was collected from a sample of 33 student participants by means of a questionnaire. The outcome was that although most students exhibited a positive attitude towards oral feedback, five had a negative attitude; they did not want the teacher to correct their errors all the time in front of other students because it made them feel nervous or frustrated.

Alamri and Fawzi (2016) also studied students' attitudes to oral CF. Drawing on a classroom observation as well as a questionnaire, data were collected from 84 Saudi female students, aged 22, who were studying English at a Saudi university. They found that the students had a positive attitude to oral CF, and that most were in favour of getting CF immediately on all types of error, which they felt were all equally important.

Hamouda's (2011) study of written feedback investigated Saudi EFL students' attitudes to written error CF; and the difficulties they faced during the feedback process. The results of the study, which was done with a sample of 200 Saudi students in the preparatory year program at a Saudi university, revealed that students had positive attitudes to written feedback, and would rather be corrected by a teacher than have to self-correct or be corrected by their peers. The amount of attention paid by the teacher to each type of error was also important for students. For example, participants believed that teachers should focus their CF on grammatical errors primarily, then on punctuation and spelling, and then vocabulary. Content, paragraph construction and organization, in that order, were seen as the next most important types of error in relation to CF.

Hassan and Dzakiria (2019) investigated 40 Pakistani learners' beliefs about written CF in L2 writing. They provided participants with two types of written CF (direct and indirect) on written tasks over a four-week period. Participants in an experimental group were compared with members of a control group, who were given no CF. Results from a questionnaire administered at the end of the study revealed that most participants preferred to get $\mathrm{CF}$ on their written errors.

A few studies have looked at both oral and written CF. One of these investigated the preferences of 58 Iranian EFL learners who were taking general English, for oral versus written CF on a variety of grammar exercises (Tonekaboni, 2016). The results indicated that students had positive attitudes to their teacher's CF and that oral feedback had a greater positive impact on students than written. Another study, with 50 university students, explored their attitudes to oral and written feedback on different types of work and found that students preferred immediate to delayed correction. They also thought that CF on written work was more useful than CF on oral work (Kavaliauskienė \& Anusienè, 2012).

From the above studies, it is apparent that knowledge about students' attitudes to CF is of great importance in designing teaching methods, and has an impact on the learning process in general, as suggested by Lightbown and Spada (2013). This study therefore focused on Saudi female students' attitudes towards both oral and written feedback. 


\section{Methodology}

\subsection{Participants and Data Collection}

This study uses a quantitative research design, with a convenience sample of 47 Saudi female university students (aged 18-20) enrolled on a foundation year, who had been learning English for an average of seven years. The sampling was not totally random. Recruiting participants at the first year was decided based on the fact that it was difficult to reach to other participants during the Covid-19 pandemic. Larson-Hall (2016) mentioned that sampling in L2 learning research is not 'random sample', as a true random sample can be found in other surveys such as political. To make the sample homogeneous, all the participants spoke the same language (Saudi Arabic) and did not live or study in an English-speaking country. The rationale for this is that all the participants should have the same background so that their attitudes are not affected by other variables.

The instrument used to collect data was an online questionnaire, with a total of 27 closed-ended questions designed to obtain students' attitudes to written and oral CF. This questionnaire is deemed to be valid and reliable given that the items on the questionnaire were adapted mainly from Diab (2005), Hamouda (2011) and Kavaliauskienè and Anusienè (2012). Close attention was paid to ethical issues during the study. The participants filled out the consent forms they were sent to them online. They were informed that their data would remain confidential and that their names would not be used in the research. The data was coded using SPSS.

\section{Results}

This section presents the questionnaire results, which are divided into the following three categories: (a) participants' opinions about written feedback; (b) their opinions about written versus oral feedback; and (c) their opinions about oral feedback. Each of the three tables that follow reports participants' opinions in each category.

Table 1. Questionnaire responses on written feedback (statements 1-8)

\begin{tabular}{|c|c|c|c|c|c|c|c|}
\hline Statement & $\begin{array}{l}\text { Strongly } \\
\text { disagree }\end{array}$ & Disagree & Uncertain & Agree & $\begin{array}{l}\text { Strongly } \\
\text { agree }\end{array}$ & Mean & SD \\
\hline \multirow[t]{2}{*}{ S.1 My teacher's written feedback is helpful. } & $1 / 47$ & $1 / 47$ & $2 / 47$ & $23 / 47$ & $20 / 47$ & 4.3 & .8 \\
\hline & $2.1 \%$ & $2.1 \%$ & $4.3 \%$ & $48.9 \%$ & $42.6 \%$ & & \\
\hline S.2 My teacher's written feedback does not improve my & $15 / 47$ & $20 / 47$ & $7 / 47$ & $5 / 47$ & - & 4 & .9 \\
\hline English. & $31.9 \%$ & $42.6 \%$ & $14.9 \%$ & $10.6 \%$ & & & \\
\hline S.3 I want my teacher to provide me with written & $1 / 47$ & - & $7 / 47$ & $21 / 47$ & $18 / 47$ & 4.2 & .8 \\
\hline $\begin{array}{l}\text { feedback on all my grammatical errors in English written } \\
\text { tasks of English. }\end{array}$ & $2.1 \%$ & & $14.9 \%$ & $44.7 \%$ & $38.3 \%$ & & \\
\hline S.4 I want my teacher to provide me with written & $1 / 47$ & $4 / 47$ & $3 / 47$ & $19 / 47$ & $20 / 47$ & 4.1 & 1 \\
\hline $\begin{array}{l}\text { feedback on all my spelling errors in English written } \\
\text { tasks. }\end{array}$ & $2.1 \%$ & $8.5 \%$ & $6.4 \%$ & $40.4 \%$ & $42.6 \%$ & & \\
\hline S.5 I want my teacher to provide me with written & $1 / 47$ & $2 / 47$ & $3 / 47$ & $21 / 47$ & $20 / 47$ & 4.2 & .9 \\
\hline $\begin{array}{l}\text { feedback on all my vocabulary errors in English written } \\
\text { tasks. }\end{array}$ & $2.1 \%$ & $4.3 \%$ & $6.4 \%$ & $44.7 \%$ & $42.6 \%$ & & \\
\hline S.6 I want my teacher to provide me with written & $4 / 47$ & - & $2 / 47$ & $24 / 47$ & $17 / 47$ & 4.1 & 1.1 \\
\hline $\begin{array}{l}\text { feedback on all my punctuation errors in English written } \\
\text { tasks. }\end{array}$ & $8.5 \%$ & & $4.3 \%$ & $51.1 \%$ & $36.2 \%$ & & \\
\hline S.7 I like my teacher's feedback to be in writing because & $2 / 47$ & - & $10 / 47$ & $18 / 47$ & $17 / 47$ & 4 & 1 \\
\hline it ensures privacy. & $4.3 \%$ & & $21.3 \%$ & $38.3 \%$ & $36.2 \%$ & & \\
\hline S.8 I don't like written feedback because sometimes I & $9 / 47$ & $19 / 47$ & $12 / 47$ & $4 / 47$ & $3 / 47$ & 3.6 & 1.1 \\
\hline cannot understand my teacher's corrections. & $19.1 \%$ & $40.4 \%$ & $25.5 \%$ & $8.5 \%$ & $6.4 \%$ & & \\
\hline
\end{tabular}

Participants expressed positive attitudes towards written feedback. Moreover, the results showed that the majority would like their teacher to provide them with written feedback on all written errors including grammar, spelling, vocabulary and punctuation errors. 
Table 2. Questionnaire responses for written versus oral feedback (statements 9-15)

\begin{tabular}{|c|c|c|c|c|c|c|c|}
\hline Statement & $\begin{array}{l}\text { Strongly } \\
\text { disagree }\end{array}$ & Disagree & Uncertain & Agree & $\begin{array}{l}\text { Strongly } \\
\text { agree }\end{array}$ & Mean & SD \\
\hline $\begin{array}{l}\text { S.9 Oral feedback improves my English more than } \\
\text { written feedback. }\end{array}$ & - & $\begin{array}{l}5 / 47 \\
10.6 \%\end{array}$ & - & $\begin{array}{l}27 / 47 \\
57.4 \%\end{array}$ & $\begin{array}{l}15 / 47 \\
31.9 \%\end{array}$ & 4.1 & .9 \\
\hline $\begin{array}{l}\text { S.10 Written feedback improves my English more than } \\
\text { oral feedback. }\end{array}$ & $\begin{array}{l}15 / 47 \\
31.9 \%\end{array}$ & $\begin{array}{l}16 / 47 \\
34 \%\end{array}$ & - & $\begin{array}{l}16 / 47 \\
34 \%\end{array}$ & - & 2.4 & 1.2 \\
\hline $\begin{array}{l}\text { S.11 I like the teacher's written feedback more than her } \\
\text { oral feedback. }\end{array}$ & $\begin{array}{l}27 / 47 \\
57.4 \%\end{array}$ & $\begin{array}{l}15 / 47 \\
31.9 \%\end{array}$ & - & - & $\begin{array}{l}5 / 47 \\
10.6 \%\end{array}$ & 1.7 & 1.2 \\
\hline $\begin{array}{l}\text { S.12 I prefer my teacher to provide me with oral } \\
\text { feedback rather than written feedback. }\end{array}$ & - & - & $\begin{array}{l}3 / 47 \\
6.4 \%\end{array}$ & $\begin{array}{l}23 / 47 \\
48.9 \%\end{array}$ & $\begin{array}{l}21 / 47 \\
44.7 \%\end{array}$ & 4.4 & .6 \\
\hline $\begin{array}{l}\text { S.13 I like my teacher to provide me with both written } \\
\text { and oral feedback. }\end{array}$ & - & $\begin{array}{l}5 / 47 \\
10.6 \%\end{array}$ & $\begin{array}{l}5 / 47 \\
10.6 \%\end{array}$ & $\begin{array}{l}23 / 47 \\
48.9 \%\end{array}$ & $\begin{array}{l}14 / 47 \\
29.8 \%\end{array}$ & 4 & .9 \\
\hline $\begin{array}{l}\text { S.14 Reading my teacher's written feedback makes me } \\
\text { feel embarrassed. }\end{array}$ & & $\begin{array}{l}2 / 47 \\
4.3 \%\end{array}$ & $\begin{array}{l}3 / 47 \\
6.4 \%\end{array}$ & $\begin{array}{l}22 / 47 \\
46.8 \%\end{array}$ & $\begin{array}{l}20 / 47 \\
42.6 \%\end{array}$ & 4.3 & .8 \\
\hline $\begin{array}{l}\text { S.15 Listening to my teacher's oral feedback is } \\
\text { embarrassing. }\end{array}$ & $\begin{array}{l}7 / 47 \\
14.9 \%\end{array}$ & - & $\begin{array}{l}7 / 47 \\
14.9 \%\end{array}$ & $\begin{array}{l}9 / 47 \\
19.1 \%\end{array}$ & $\begin{array}{l}24 / 47 \\
51.1 \%\end{array}$ & 3.9 & 1.4 \\
\hline
\end{tabular}

Overall, most of the students exhibited a more positive attitude to oral than written feedback. They agreed that it was more useful for helping them improve their English than written feedback. However, in spite of these positive attitudes to oral feedback, most students still felt that it was embarrassing to have to listen to their tutor giving feedback on their work out loud.

Table 3. Questionnaire responses for oral feedback (statements 16-27)

\begin{tabular}{|c|c|c|c|c|c|c|c|}
\hline Statement & $\begin{array}{l}\text { Strongly } \\
\text { disagree }\end{array}$ & Disagree & Uncertain & Agree & $\begin{array}{l}\text { Strongly } \\
\text { agree }\end{array}$ & Mean & SD \\
\hline \multirow[t]{2}{*}{ S.16 My teacher's oral feedback improves my speaking. } & - & $1 / 47$ & $6 / 47$ & $27 / 47$ & $13 / 47$ & 4.1 & .7 \\
\hline & & $2.1 \%$ & $12.8 \%$ & $57.4 \%$ & $27.7 \%$ & & \\
\hline \multirow[t]{2}{*}{ S.17 I don't think my teacher's oral feedback is effective. } & $17 / 47$ & $21 / 47$ & $6 / 47$ & $2 / 47$ & $1 / 47$ & 4.1 & .9 \\
\hline & 36.2 & $44.7 \%$ & $12.8 \%$ & $4.1 \%$ & $2.1 \%$ & & \\
\hline \multirow{2}{*}{$\begin{array}{l}\text { S.18 When I speak English, I want my teacher to provide } \\
\text { me with oral feedback on every grammatical error I } \\
\text { make. }\end{array}$} & $1 / 47$ & $5 / 47$ & $5 / 47$ & $24 / 47$ & $12 / 47$ & 3.9 & 1 \\
\hline & $2.1 \%$ & $10.6 \%$ & $10.6 \%$ & $51.1 \%$ & $25.5 \%$ & & \\
\hline \multirow{2}{*}{$\begin{array}{l}\text { S.19 When I speak English, I want my teacher to provide } \\
\text { me with oral feedback on every error I make in my } \\
\text { pronunciation. }\end{array}$} & - & $2 / 47$ & $8 / 47$ & $24 / 47$ & $13 / 47$ & 4 & .8 \\
\hline & & $4.3 \%$ & $17 \%$ & $51 \%$ & $27.7 \%$ & & \\
\hline \multirow{2}{*}{$\begin{array}{l}\text { S. } 20 \text { When I speak English, I want my teacher to provide } \\
\text { me with oral feedback on all my vocabulary errors. }\end{array}$} & - & $2 / 47$ & - & $32 / 47$ & $13 / 47$ & 4.2 & .6 \\
\hline & & $4.3 \%$ & & $68 \%$ & $27.7 \%$ & & \\
\hline \multirow{2}{*}{$\begin{array}{l}\text { S.21 I prefer my teacher not to provide me with oral } \\
\text { feedback in front of my classmates. }\end{array}$} & $2 / 47$ & $7 / 47$ & $10 / 47$ & $12 / 47$ & $16 / 47$ & 3.7 & 1.2 \\
\hline & $4.3 \%$ & $14.9 \%$ & $21.3 \%$ & $25.5 \%$ & $34 \%$ & & \\
\hline \multirow{2}{*}{$\begin{array}{l}\text { S.22 Oral feedback allows me to interact with my teacher } \\
\text { to understand my errors better. }\end{array}$} & - & $2 / 47$ & $8 / 47$ & $24 / 47$ & $13 / 47$ & 4 & .8 \\
\hline & & $4.3 \%$ & $17 \%$ & $51.1 \%$ & $27.7 \%$ & & \\
\hline \multirow[t]{2}{*}{ S.23 I think all my written errors should be corrected. } & - & - & $4 / 47$ & $25 / 47$ & $18 / 47$ & 4.3 & 6 \\
\hline & & & $8.5 \%$ & $53.2 \%$ & $38.3 \%$ & & \\
\hline \multirow{2}{*}{$\begin{array}{l}\text { S. } 24 \text { If I make errors when speaking, I would like to be } \\
\text { corrected. }\end{array}$} & $1 / 47$ & - & $8 / 47$ & $28 / 47$ & $10 / 47$ & 4 & .8 \\
\hline & $2.1 \%$ & & $17 \%$ & $59.6 \%$ & $21.3 \%$ & & \\
\hline S.25 I prefer to get immediate oral feedback on the errors & $4 / 47$ & $8 / 47$ & $5 / 47$ & $20 / 47$ & $10 / 47$ & 3.5 & 1.2 \\
\hline I make while I am speaking. & $8.5 \%$ & $17 \%$ & $10.6 \%$ & $42.6 \%$ & $21.3 \%$ & & \\
\hline S.26 I prefer it when my teacher focuses more on my & $15 / 47$ & $13 / 47$ & $9 / 47$ & $10 / 47$ & & 2.3 & 1.1 \\
\hline written errors than my oral errors. & $31.9 \%$ & $27.7 \%$ & $19.1 \%$ & $21.3 \%$ & - & & \\
\hline S.27 I feel nervous when my teacher corrects my errors & $3 / 47$ & $6 / 47$ & $7 / 47$ & $19 / 47$ & $12 / 47$ & 3.7 & 1.2 \\
\hline in front of other students. & $6.4 \%$ & $12.8 \%$ & $14.9 \%$ & $40.4 \%$ & 25.5 & & \\
\hline
\end{tabular}

This table shows that participants had positive attitudes to oral feedback and want their teacher to provide them with immediate feedback on all oral errors, including errors of grammar, pronunciation and vocabulary. However, participants were not keen for their teacher to correct them in front of other students as this made them nervous. 


\section{Discussion}

This section discusses the results of the questionnaire. The statements were grouped into three categories-a) opinions about written feedback; b) opinions about written versus oral feedback; and c) opinions about oral feedback. These are discussed in turn below.

By far the greatest proportion of students in the sample expressed a positive attitude to written feedback $(48.9 \%$ agreed, $42.6 \%$ strongly agreed). Moreover, the results showed that most students in the sample also wanted written feedback on grammar, spelling, vocabulary and punctuation. This suggests that it was important to them to have all their written errors corrected by the teacher, thus replicating the results of the work done by Hamouda (2011) and Hassan and Dzakiria (2019), and perhaps an indication that they would like to learn how to produce perfect written work in future.

With regard to the second construct, the results contradict those achieved by Kavaliauskienè and Anusienè (2012) but replicate those of Tonekaboni (2016), who found that most had a more positive attitude towards oral than written feedback. It is perhaps surprising that in spite of their positive attitude to being corrected, most of the students in the study still felt uncomfortable about receiving feedback from the teacher.

The results in the third table, which are derived from the statements in the third construct, replicate the results achieved by Alamri and Fawzi (2016). The participants displayed positive attitudes to oral feedback and wanted their teacher to focus on all their oral errors, including errors of grammar and pronunciation as well as vocabulary. Moreover, students preferred it when their teacher provided them with immediate CF, which is in line with what was found by Kavaliauskienè and Anusienè (2012). However, they did not want their teacher to correct them in front of other students as this made them nervous, as the work of Septiana, Daud, and Heriansyah (2016) also showed. In spite of their positive attitude to oral feedback, students found it embarrassing to get this in front of other students. This in turn may make students lose confidence and could have a potential to affect the feedback.

Students' responses to all statements point to the conclusion that CF provision in class is a crucial part of improving their English, and suggest that they would like to be given the correct forms of their written and oral errors. Yet, even as they find CF useful, students still feel embarrassed to receive it.

This study has a number of limitations; first of all because it focused only on university-level students' attitudes to CF. Future research should therefore also explore school students' attitudes. Moreover, the study was also limited by its focus on students; future research should also investigate teachers' attitudes to different types of feedback.

\section{Conclusion}

CF indisputably plays a key role in teaching - and not just in the teaching of English — as it can help students understand and correct their mistakes. However, for it to be effective, it is important that students have a positive attitude both to the type of feedback and the way it is delivered. On the whole, this study showed that most participants preferred to receive $\mathrm{CF}$ on all their written and oral errors. Although most agreed that they preferred oral to written CF, and that this was more effective at helping them improve their English, the findings also showed that they did not want to be corrected in front of other students as this could make them nervous. Ultimately, what emerges from this study, as from the other studies cited above, is that teachers need to understand their students' attitudes to CF, and to be able to make them aware of its importance and how it contributes to their progress. It is highly recommended that L2 teachers of English in Saudi Arabia take note of this, particularly those who teach at university level.

\section{References}

Alamri, B., \& Fawzi, H. H. (2016). Students' Preferences and Attitude toward Oral Error Correction Techniques at Yanbu University College, Saudi Arabia. English Language Teaching, 9(11), 59-66. https://doi.org/10.5539/elt.v9n11p59

Brookhart, S. M. (2008). How to Give Effective Feedback to Your Students. Alexandria: Association for Supervision and Curriculum Development.

Diab, R. L. (2005). EFL university students' preferences for error correction and teacher feedback to writing. TESL Reporter, 38(1), 27-51.

Ellis, R. (2009). Corrective feedback and teacher development. L2 Journal, 1(1), 3-18. https://doi.org/10.5070/L2.V1I1.9054

Ellis, R., Sheen, Y., Murakami, M., \& Takashima, H. (2008). The effects of focused and unfocused written 
corrective feedback in an English as a foreign language context. System, 36(3), 353-371. https://doi.org/10.1016/j.system.2008.02.001

Ferris, D. R. (2002). Treatment of error in second language student writing. Ann Arbor: The University of Michigan Press.

Hadzic, S. (2016). Oral and written teacher feedback in an English as a foreign language classroom in Sweden. Unpublished doctoral thesis, Linnaeus University, Sweden.

Hamouda, A. (2011). A Study of Students' and Teachers' Preferences and Attitudes towards Correction of Classroom Written Errors in Saudi EFL Context. English Language Teaching, 4(3), 128-141. https://doi.org/10.5539/elt.v4n3p128

Hassan, M., \& Dzakiria, H. (2019). University Students' Beliefs towards Corrective Feedback in Learning English as Foreign Language in Pakistan. International Journal of Recent Technology and Engineering, 8(3), 4094-4100. https://doi.org/10.35940/ijrte.C5465.098319

Hyland, F. (2003). Focusing on form: Student engagement with teacher feedback. System, 31(2), 217-230. https://doi.org/10.1016/S0346-251X(03)00021-6

Kavaliauskienè, G., \& Anusienè, L. (2012). Case study: Learner attitudes towards the correction of mistakes. Social Technologies, 2(1), 88-101.

Larson-Hall, J. (2016). A Guide to Doing Statistics in Second Language Research Using SPSS. Routledge: London. https://doi.org/10.4324/9781315775661

Lightbown, P., \& Spada, N. (1999). How languages are learned. Oxford: Oxford University Press.

Lightbown, P. M., \& Spada, N. (2013). How languages are learned 4th edition-Oxford Handbooks for Language Teachers. Oxford university press.

Lyster, R., \& Ranta, L. (1997). Corrective feedback and learner uptake: Negotiation of form in communicative classrooms. Studies in Second Language Acquisition, 37-66. https://doi.org/10.1017/S0272263197001034

Lyster, R., Saito, K., \& Sato, M. (2013). Oral corrective feedback in second language classrooms. Language Teaching, 46(1), 1. https://doi.org/10.1017/S0261444812000365

Mahdi, D., \& Saadany, N. (2013). Oral Feedback in the EFL classroom. Malmo Hohskoala, 11-27.

Quinn, P. (2014). Delayed versus immediate corrective feedback on orally produced passive errors in English. University of Toronto Toronto.

Russell, J., \& Spada, N. (2006). The effectiveness of corrective feedback for the acquisition of L2 grammar. Synthesizing Research on Language Learning and Teaching, 13, 133-164. https://doi.org/10.1075/11lt.13.09val

Septiana, Y., Daud, B., \& Heriansyah, H. (2016). Students' Perceptions on Teacher's Oral Feedback. Research in English and Education Journal, 1(1), 18-25.

Sheen, Y. (2007). The effect of focused written corrective feedback and language aptitude on ESL learners' acquisition of articles. Tesol Quarterly, 41(2), 255-283. https://doi.org/10.1002/j.1545-7249.2007.tb00059.x

Talib, R., Naim, H. A., \& Supie, H. S. M. (2015). UTM postgraduate students' perspective on feedback practices in higher education. International Education Studies, 8(13), 17-21. https://doi.org/10.5539/ies.v8n13p17

Tonekaboni, A. M. (2016). Effective feedback in second language acquisition: Oral feedback vs. written feedback. International Research Journal of Applied and Basic Sciences, 10(2), 153-165.

\section{Copyrights}

Copyright for this article is retained by the author, with first publication rights granted to the journal.

This is an open-access article distributed under the terms and conditions of the Creative Commons Attribution license (http://creativecommons.org/licenses/by/4.0/). 